\title{
Evaluasi Kandungan Nutrien dan Antinutrien Tepung Daun Kelor Terfermentasi sebagai Bahan Baku Pakan Ikan
}

\section{An Evaluation of Nutrient Value and Antinutritional Contents of Fermented Moringa oleifera Leaves Meal as Fish Feed Ingredient}

\author{
Senny Helmiati" ${ }^{*}$, Rustadi Rustadi' ${ }^{1}$ Alim Isnansetyo ${ }^{1}$ \& Zuprizal Zuprizal \\ 'Departemen Perikanan, Fakultas Pertanian, Universitas Gadjah Mada, Yogyakarta Indonesia \\ 2Departemen Nutrisi dan Makanan Ternak, Fakultas Peternakan, Universitas Gadjah Mada, Indonesia \\ *Corresponding author, e-mail: senny@ugm.ac.id
}

Submitted 30 September 2020 Revised 04 November 2020 Accepted 30 November 2020

\begin{abstract}
ABSTRAK Penelitian ini bertujuan untuk mengevaluasi kandungan nutrien dan antinutrien tepung daun kelor terfermentasi sebagai sumber protein nabati pakan ikan. Tahap penelitian meliputi pembuatan tepung daun kelor, persiapan dan penghitungan kepadatan bakteri, proses fermentasi, dan analisis kandungan nutrien dan antinutriennya. Bakteri yang digunakan untuk fermentasi merupakan campuran bakteri T2A (Bacillus sp.), T3P1 (Bacillus sp.) dan JAL11 (Lactococcus raffinolactis) dengan kepadatan sebesar 2,16x10 $\mathrm{cfu} / \mathrm{mL}$. Fermentasi tepung daun kelor dilakukan selama $168 \mathrm{jam}$. Analisis kandungan nutrien dan zat antinutrien tepung daun kelor terfermentasi dilakukan pada jam ke-24, ke-48, ke-72, ke-96, ke-120, ke-144 dan ke-168. Kandungan nutrien tepung daun kelor meliputi kadar air $(9,04 \pm 0,00 \%)$, abu $(9,70 \pm 0,21 \%)$, protein $(25,77 \pm 0,08 \%)$, lemak $(4,80 \pm 0,52 \%)$, serat kasar $(11,60 \pm 0,13 \%)$, bahan ekstrak tanpa nitrogen $(39,06 \pm 0,52 \%)$, energi $(351,27 \pm 3,27 \mathrm{kkal} / 00 \mathrm{~g})$, hemiselulosa $(13,79 \pm 0,07 \%)$, selulosa $(9,9 \pm 0,06 \%)$ dan lignin $(15,34 \pm 0,31 \%)$. Fermentasi dapat meningkatkan kadar air, abu, protein dan lemak, serta menurunkan kadar serat kasar, bahan ekstrak tanpa nitrogen, hemiselulosa, selulosa, lignin dan antinutrien, antara lain fenol, tanin, asam fitat dan HCN. Hasil penelitian menunjukkan bahwa fermentasi dapat meningkatkan kandungan nutrien dan menurunkan kandungan antinutrien tepung daun kelor, sehingga dapat digunakan sebagai sumber protein nabati pada bahan baku pakan ikan.
\end{abstract}

Kata kunci: Antinutrien; daun kelor; fermentasi; nutrien; pakan ikan

ABSTRACT The aim of the study was to evaluate nutritive value and antinutritional contents of fermented Moringa oleifera leaves meal as a plant-based protein source as an alternative ingredient for aquafeed. The research stages included processing of $M$. oleifera leaf meal, preparation and calculation of bacterial density, fermentation process, and analysis of nutrient and antinutrient content. The bacteria used for fermentation is a mixture of T2A (Bacillus sp.), T3P1 (Bacillus sp.) and JAL11 (Lactococcus raffinolactis) bacteria with a density of $2.16 \times 10^{9} \mathrm{cfu} / \mathrm{mL}$. Fermented M. oleifera leaves meal was carried out for 168 hours. Analysis of nutrient content and antinutrient substances of fermented $M$. oleifera leaves meal was carried out at 24, 48, 72, 96, 120, 144 and 168 hours. The nutrient content of Moringa leaf meal includes moisture $(9.04 \pm 0.00 \%)$, ash $(9.70 \pm 0.21 \%)$, protein $(25.77 \pm 0.08 \%)$, fat $(4.80 \pm$ $0.52 \%)$, crude fiber $(11.60 \pm 0.13 \%)$, extract material without nitrogen $(39.06 \pm 0.52 \%)$, energy $(351.27 \pm 3.27$ $\mathrm{kcal} / 100 \mathrm{~g})$, hemicellulose $(13.79 \pm 0.07 \%)$, cellulose $(9.9 \pm 0.06 \%)$ and lignin $(15.34 \pm 0.31 \%)$. Fermentation can increase moisture, ash, protein and fat content, and reduce crude fiber content, nitrogen free extract, hemicellulose, cellulose, lignin and antinutrients, including phenols, tannins, phytic acid and HCN. The results of the present study show that fermentation is able to improve nutrient dan decrease antinutritional content of $M$. oleifera leaves meal as a plant-based protein source for further use in aquafeed ingredient.

Keywords: Antinutritional content; Moringa oleifera leaves meal; fermentation; nutritive value; aquafeed

\section{PENDAHULUAN}

Tepung ikan merupakan bahan pakan sumber protein terbaik yang sering digunakan dalam formulasi pakan ikan karena mempunyai kadar protein tinggi, profil asam aminonya lengkap, tingkat kecernaannya tinggi dan zat antinutriennya rendah (Barrows et al., 2008). Akan tetapi, rendahnya pasokan tepung ikan dan tingginya permintaan konsumen menyebabkan meningkatnya harga bahan pakan tersebut (Lunger et al., 2007). Tepung kedelai merupakan bahan pakan sumber protein nabati terbaik yang digunakan sebagai pengganti tepung ikan (Omnes et al., 2017). Di Indonesia, tepung kedelai juga digunakan sebagai bahan pakan sumber protein nabati, akan tetapi, karena harus didatangkan dari luar negeri maka harganya menjadi mahal (Karina et al., 2015). Produk tepung kedelai dalam negeri tidak mampu memenuhi kebutuhan pabrik pakan, padahal permintaannya terus meningkat. Kondisi tersebut memacu pengembangan sumber protein nabati dengan daya cerna dan palatabilitas tinggi sebagai pengganti tepung ikan dan tepung kedelai dalam pakan. Berbagai macam sumber protein pengganti tepung ikan telah dievaluasi untuk meningkatkan pemanfaatan pakan dan/atau kinerja pertumbuhan beberapa spesies ikan, untuk mengatasi keterbatasan penggunaan sumber bahan pakan tunggal (Seong et al., 2018). 
Daun kelor (Moringa oleifera Lam.) merupakan salah satu sumber protein nabati yang mengandung protein sebesar 30,3\% dan mempunyai 19 macam asam amino (Moyo et al., 2011), vitamin B, C, K, beta karoten (Ganzon-Naret, 2014) dan mineral lainnya (Madalla et al., 2013). Daun kelor memiliki energi tinggi dan fenolik, terutama asam flavonoid dan asam fenolat sebagai sumber antioksidan alami (Valdez-Solana et al., 2015). Akan tetapi, daun kelor juga mengandung zat antinutrien, seperti saponin, tanin, asam fitat dan HCN (Francis et al., 2001). Beberapa zat antinutrien dapat mengurangi kecernaan protein dan menyebabkan efek toksisitas, seperti menghambat pembentukan sel darah merah dan menekan respon imun (Lovell, 1989).

Fermentasi adalah teknik untuk meningkatkan kualitas nutrien dari produk pertanian supaya cocok dimasukkan dalam komponen formulasi pakan sebagai sumber protein (Bertsch \& Coello, 2005). Fermentasi dapat menurunkan kandungan zat antinutrien, meningkatkan kadar protein kasar, menurunkan kadar serat kasar tanaman sehingga meningkatkan kandungan nutriennya (El-Batal \& Abdel Karem, 2001). Fermentasi pakan ikan dengan Saccharomyces cerevisiae selama 72 jam dapat meningkatkan kadar protein pakan sampai dengan 31,68\% (Qazi et al., 2001). Fermentasi tepung kedelai menggunakan Bacillus spp. dengan perlakuan panas dapat digunakan sebagai sumber protein utama pakan Rainbow trout (Yamamoto et al., 2010). Fermentasi bahan padat (solid-state fermentation) dapat digunakan untuk meningkatkan pelepasan nutrien dalam tepung daun kelor (Zhang et al., 2017). Penelitian ini bertujuan untuk mengevaluasi kandungan nutrien tepung daun kelor terfermentasi sebagai sumber protein nabati yang berperan sebagai bahan pakan alternatif bagi pakan ikan dengan mengukur beberapa parameter, yaitu kadar air, protein, lemak, abu, serat kasar, BETN, energi, asam amino, kalsium, fosfor, lignin, selulosa dan hemiselulosa serta zat antinutrien (fenol, tanin, asam fitat dan HCN).

\section{BAHAN DAN METODE}

\section{Bahan}

Bahan-bahan yang digunakan dalam penelitian ini meliputi daun kelor yang diperoleh dari Kabupaten Bantul dan Kulon Progo, Daerah Istimewa Yogyakarta, campuran bakteri T2A (Bacillus sp.), T3P1 (Bacillus sp.) dan JAL11 (Lactococcus raffinolactis) yang merupakan produk dari Laboratorium Kesehatan Ikan dan Lingkungan Departemen Perikanan Fakultas Pertanian Universitas Gadjah Mada, Phospat Buffer Saline (PBS) steril, akuades, tablet Kjeldahl, $0,02 \mathrm{~N} \mathrm{HCl}$ (MERCK), $\mathrm{HNO}_{3}$ (MERCK), N-heksan (teknis), $\mathrm{NH}_{4} \mathrm{OH}$ (MERCK), indikator BCG-MR, asam oksalat, $\mathrm{H}_{2} \mathrm{SO}_{4}$ pekat, asam borat $4 \%, \mathrm{H}_{2} \mathrm{SO}_{4}, \mathrm{KMnO}_{4^{\prime}}$ vanadat molibdat, $\mathrm{HCl}, \mathrm{NaOH}$, larutan Follin denis, $\mathrm{Na}_{2} \mathrm{CO}_{3^{\prime}} \mathrm{NaCO}_{3^{\prime}}$ Iarutan pikrat, $\mathrm{FeCl}_{3}$, Trichloro Acetic Acid (TCA), amonium tiosianat, Tryptone Soy Agar (TSA) (MERCK), Tryptone Soy Broth (TSB) (MERCK), skim milk agar (MERCK), CMC agar (MERCK), starch $\operatorname{agar}(\mathrm{MERCK}), \mathrm{H}_{2} \mathrm{O}, 30 \% \mathrm{AA}$ (Acrylamide), 1,5 Tris $\mathrm{HCl}, 10 \%$ SDS (Dodeyclsulfat Natriumsalz), 10\% APS (Amonium persulfate), akuabides, Commasie Brilliant Blue, asam asetat $10 \%$ dan marker Precision Plus Protein ${ }^{T M}$ Standards BIO-RAD 4110029 Rev B. Separating gel $\left(\mathrm{H}_{2} \mathrm{O} 2950 \mu \mathrm{L}, 30 \%\right.$ acrylamide $2500 \mu \mathrm{L}, 1,5$ tris $\mathrm{HCl} 1900 \mu \mathrm{L} \mathrm{pH} \mathrm{8,8,10 \%} \mathrm{Sodium} \mathrm{Deodecyl}$ Sulfat Natriumsalz $75 \mu \mathrm{L}, 10 \%$ APS (Ammonium Persulfate)
$75 \mu \mathrm{L}, \mathrm{TEMED}$ (Tetramethylethylenediamine) $3 \mu \mathrm{L}$ ) dan stacking gel $\left(\mathrm{H}_{2} \mathrm{O} 1350 \mu \mathrm{L}, 30 \%\right.$ acrylamide $335 \mu \mathrm{L}, 1,5$ Tris $\mathrm{HCl} 250 \mu \mathrm{L} \mathrm{pH} \mathrm{6,8,10 \%} \mathrm{Sodium} \mathrm{deodecylsulfat} \mathrm{natriumsalz}$ $20 \mu \mathrm{L}, 10 \%$ APS (Ammonium Persulfate) $20 \mu \mathrm{L}$, TEMED (Tetramethylethylenediamine) $2 \mu \mathrm{L}$. Running buffer (Tris- $\mathrm{HCl}$, gliserol, SDS, merkaptoetanol, dan bromfenol biru).

Metode

\section{Pembuatan tepung daun kelor}

Daun kelor dipisahkan dari tangkainya, selanjutnya daun dikeringkan dalam oven dengan suhu $60^{\circ} \mathrm{C}$ selama 6-8 jam. Daun yang sudah kering digiling, diayak menggunakan saringan dengan mesh size $1 \mathrm{~mm}$ dan dimasukkan dalam kantong plastik kedap udara dan disimpan dalam refrigerator pada suhu $5^{\circ} \mathrm{C}$.

Tabel 1. Karakteristik tiga isolat bakteri yang digunakan untuk memfermentasi tepung daun kelor.

\begin{tabular}{|c|c|c|c|}
\hline \multirow[t]{2}{*}{ Keterangan } & \multicolumn{3}{|l|}{ Nama Isolat } \\
\hline & T2A & T3P1 & JAL11 \\
\hline Asal & Sumatera & Sumatera & Jepara \\
\hline Sumber sampel & Terasi 2 & Terasi 3 & $\begin{array}{l}\text { Ikan cucut } \\
\text { merah }\end{array}$ \\
\hline \multicolumn{4}{|l|}{ Aktivitas: } \\
\hline - Proteolitik & $(-)$ & $(+)$ & $(+)$ \\
\hline - Amilolitik & $(+)$ & $(+)$ & $(+)$ \\
\hline - Selulolitik & $(+)$ & $(+)$ & $(-)$ \\
\hline - Asam laktat & $(+)$ & $(+)$ & $(+)$ \\
\hline Gram & Positif & Positif & Positif \\
\hline Bentuk & Batang & Batang & Coccus \\
\hline Jenis & Bacillus sp. & Bacillus sp. & $\begin{array}{l}\text { Lactobacillus } \\
\text { raffinolactis }\end{array}$ \\
\hline
\end{tabular}

Fakultas Pertanian, Universitas Gadjah Mada.

Keterangan:

(-): tidak tumbuh; (+): tumbuh

\section{Persiapan bakteri}

Bakteri diambil dari tiga jenis sumber (Tabel 1), diisolasi pada medium TSA dengan metode gores untuk kemudian ditumbuhkan selama 24 jam dalam inkubator pada suhu $30^{\circ} \mathrm{C}$. Pemurnian dilakukan dengan menumbuhkan kembali isolat, ke medium TSA dengan metode gores (McFaddin, 1980). Perbanyakan campuran bakteri dilakukan dengan mencampurkan $1 \mathrm{~g}$ campuran bakteri dalam filler komersial ke dalam $100 \mathrm{~mL}$ TSB dan diinkubasi selama 24 jam di atas waterbath shaker Rev. 90 pada suhu $30^{\circ} \mathrm{C}$. Kepadatan campuran bakteri T2A (Bacillus sp.), T3P1 (Bacillus sp.) dan JAL11 (L. raffinolactis) dihitung menggunakan metode TPC. Metode tersebut diawali dengan membuat seri pengenceran dari $10^{1}$ sampai dengan $10^{6}$ masing-masing pada media TSA. Sebanyak $100 \mu \mathrm{L}$ pengenceran dituang pada medium TSA, selanjutnya diratakan menggunakan drigalski steril hingga permukaan media kering sempurna, kemudian diinkubasi dalam inkubator pada suhu $30^{\circ} \mathrm{C}$ selama 24 jam. Setelah itu jumlah koloni yang tumbuh dihitung dan dikalikan dengan besaran pengenceran yang telah dilakukan. Kepadatan campuran bakteri yaitu sebesar $2,16 \times 10^{9} \mathrm{CFU} / \mathrm{mL}$. 
Penghitungan bakteri dalam tepung daun kelor terfermentasi dengan metode TPC

Proses penghitungan bakteri dalam tepung daun kelor dengan metode TPC dilakukan setiap 24 jam selama 168 jam fermentasi. Tepung daun kelor terfermentasi diambil cuplikannya secara acak sebanyak $5 \mathrm{~g}$, kemudian dicampur ke dalam $15 \mathrm{~mL}$ PBS steril dalam tabung falkon ukuran $50 \mathrm{~mL}$, kemudian dibuat seri pengenceran dari $10^{1}$ sampai dengan $10^{6}$ masing-masing pada media skim milk agar, CMC agar dan starch agar. Medium skim milk agar digunakan untuk mengetahui jumlah bakteri proteolitik dengan mengamati zona bening pada medium, CMC agar digunakan untuk mengetahui jumlah bakteri selulolitik dengan mengamati zona bening pada medium setelah ditambahkan cat congo red dan strach agar untuk mengetahui jumlah bakteri amilolitik dengan mengamati zona bening pada medium ditambahkan iodin.

Tabel 2. Jumlah koloni bakteri dari campuran bakteri T2A (Bacillus sp.), T3P1 (Bacillus sp.) dan JAL11 (L. raffinolactis) pada berbagai seri pengenceran.

\begin{tabular}{llllllll}
\hline Pengenceran & \multicolumn{2}{l}{ Jumlah koloni pada jam ke- } & & & \\
\cline { 2 - 8 } & $\mathbf{2 4}$ & $\mathbf{4 8}$ & $\mathbf{7 2}$ & $\mathbf{9 6}$ & $\mathbf{1 2 0}$ & $\mathbf{1 4 4}$ & $\mathbf{1 6 8}$ \\
\hline $10^{1}$ & $>300$ & $>300$ & $>300$ & $>300$ & $>300$ & $>300$ & $>300$ \\
$10^{2}$ & $>300$ & $>300$ & $>300$ & $>300$ & $>300$ & $>300$ & $>300$ \\
$10^{3}$ & $>300$ & $>300$ & $>300$ & $>300$ & $>300$ & $>300$ & $>300$ \\
$10^{4}$ & 171 & 262 & 135 & 284 & $>300$ & $>300$ & $>300$ \\
$10^{5}$ & 45 & 65 & 11 & 39 & $>300$ & $>300$ & $>300$ \\
$10^{6}$ & 9 & 4 & 1 & 2 & 110 & 121 & 216 \\
\hline Jumlah bakteri $(\mathrm{CFU} / \mathrm{mL})$ & $5,07 \times 10^{7}$ & $4,37 \times 10^{7}$ & $1,15 \times 10^{7}$ & $2,91 \times 10^{7}$ & $1,1 \times 10^{9}$ & $1,21 \times 10^{9}$ & $2,16 \times 10^{9}$ \\
\hline \hline
\end{tabular}

Tabel 3. Jumlah koloni campuran bakteri T2A (Bacillus sp.), T3P1 (Bacillus sp.) dan JAL11 (L. raffinolactis) pada media starch agar skim milk agar dan $C M C$ agar pada berbagai seri pengenceran.

\begin{tabular}{|c|c|c|c|c|c|c|c|}
\hline \multirow[t]{2}{*}{ Pengenceran } & \multicolumn{7}{|c|}{ Jumlah koloni pada jam ke- } \\
\hline & 24 & 48 & 72 & 96 & 120 & 144 & 168 \\
\hline \multicolumn{8}{|l|}{ Strach agar } \\
\hline $10^{1}$ & $>300$ & $>300$ & $>300$ & $>300$ & $>300$ & $>300$ & $>300$ \\
\hline $10^{2}$ & $>300$ & $>300$ & $>300$ & $>300$ & $>300$ & $>300$ & $>300$ \\
\hline $10^{3}$ & 29 & $>300$ & $>300$ & $>300$ & $>300$ & $>300$ & $>300$ \\
\hline $10^{4}$ & 11 & 32 & 30 & 30 & 22 & $>300$ & 30 \\
\hline $10^{5}$ & 16 & 9 & 7 & 16 & 1 & 100 & 9 \\
\hline $10^{6}$ & 0 & 11 & 0 & 8 & 5 & 20 & 12 \\
\hline \multicolumn{8}{|c|}{ Jumlah bakteri (CFU/mL) } \\
\hline & $0,63 \times 10^{6}$ & $0,67 \times 10^{7}$ & $3,65 \times 10^{6}$ & $3,3 \times 10^{6}$ & $2,07 \times 10^{6}$ & $1,5 \times 10^{7}$ & $0,71 \times 10^{7}$ \\
\hline \multicolumn{8}{|c|}{ Skim milk agar } \\
\hline $10^{1}$ & $>300$ & $>300$ & $>300$ & $>300$ & $>300$ & $>300$ & $>300$ \\
\hline $10^{2}$ & 21 & $>300$ & $>300$ & $>300$ & $>300$ & $>300$ & $>300$ \\
\hline $10^{3}$ & 2 & $>300$ & $>300$ & $>300$ & $>300$ & $>300$ & $>300$ \\
\hline $10^{4}$ & 0 & 9 & 9 & 4 & $>300$ & $>300$ & $>300$ \\
\hline $10^{5}$ & 0 & 10 & 5 & 3 & $>300$ & 100 & $>300$ \\
\hline $10^{6}$ & 0 & 0 & 0 & 0 & 13 & 7 & 4 \\
\hline \multicolumn{8}{|c|}{ Jumlah bakteri (CFU/mL) } \\
\hline & $2,05 \times 10^{3}$ & $0,54 \times 10^{6}$ & $2,95 \times 10^{5}$ & $1,7 \times 10^{5}$ & $1,3 \times 10^{7}$ & $2,76 \times 10^{7}$ & $4 \times 10^{7}$ \\
\hline \multicolumn{8}{|l|}{ CMC agar } \\
\hline $10^{1}$ & 0 & 0 & $>300$ & $>300$ & $>300$ & $>300$ & $>300$ \\
\hline $10^{2}$ & 0 & 0 & $>300$ & $>300$ & $>300$ & $>300$ & $>300$ \\
\hline $10^{3}$ & 0 & 0 & $>300$ & $>300$ & $>300$ & $>300$ & $>300$ \\
\hline $10^{4}$ & 0 & 0 & 4 & 23 & $>300$ & 33 & 16 \\
\hline $10^{5}$ & 0 & 0 & 1 & 3 & $>300$ & 9 & 14 \\
\hline $10^{6}$ & 0 & 0 & 0 & 4 & 12 & 2 & 8 \\
\hline \multicolumn{8}{|c|}{ Jumlah bakteri (CFU/mL) } \\
\hline & 0 & 0 & $0,7 \times 10^{5}$ & $1,51 \times 10^{6}$ & $1,2 \times 10^{7}$ & $1,07 \times 10^{6}$ & $3,67 \times 10^{6}$ \\
\hline
\end{tabular}




\section{Fermentasi tepung daun kelor}

Fermentasi dilakukan dengan mengambil $50 \mathrm{~mL}$ campuran bakteri yang telah ditumbuhkan dalam media TSB steril selama 24 jam ditambah dengan $450 \mathrm{~mL}$ PBS steril kemudian dihomogenkan, setelah itu dicampur dengan $500 \mathrm{~g}$ tepung daun kelor hingga merata, dimasukkan dalam ke dalam nampan secara merata kemudian ditutup rapat dan difermentasi selama 168 jam. Pengambilan sampel tepung daun kelor terfermentasi dilakukan setiap 24 jam, mulai jam ke-24 sampai dengan jam ke-168, masing-masing sebanyak $5 \mathrm{~g}$. Sampel yang diambil setiap hari dikeringkan pada suhu $40^{\circ} \mathrm{C}$ selama 7 jam, kemudian dihaluskan, disimpan dalam plastik kedap udara dan siap untuk dianalisis proksimat.

\section{Analisis kandungan nutrien dan antinutrien tepung daun kelor dan tepung daun kelor terfermentasi}

Analisis kandungan nutrien tepung daun kelor dan tepung daun terfermentasi meliputi uji kadar protein kasar, lemak kasar (metode Soxlet), air, abu, serat kasar, kalsium dan fosfor (AOAC, 2005). Metode micro-Kjeldahl digunakan untuk menganalisis kadar protein kasar dengan mengalikan nilai $\mathrm{N}$ dengan 6,25. Nilai bahan ekstrak tanpa nitrogen ditentukan dengan cara mengurangi 100 dengan penjumlahan kadar air, abu, protein kasar, lemak dan serat kasar. Kadar hemiselulosa, selulosa dan lignin dianalisis menggunakan metode Cheson (1978) dan Datta (1981). Kadar fenol dan tanin ditentukan dengan menggunakan metode spektrofotometri (Harborne, 1984). Kadar asam fitat ditentukan menggunakan metode Wheeler \& Ferrel (1971). Analisis kandungan nutrien dilakukan pada jam ke-24, ke-48, ke-72, ke-96, ke-120, ke-144 dan ke-168. Cuplikan sampel diambil sebanyak tiga kali untuk tiap-tiap parameter analisis.

\section{Analisis kandungan asam amino tepung daun kelor}

Analisis kandungan nutrien dan zat antinutrien dilakukan pada jam ke-24, ke-48, ke-72, ke-96, ke-120, ke-144 dan ke-168. Cuplikan sampel diambil sebanyak tiga kali untuk tiap-tiap parameter analisis. Setiap 24 jam, cuplikan sampel diambil sebanyak $2 \mathrm{~g}$, ditimbang dan dimasukkan ke dalam tabung reaksi ukuran $50 \mathrm{~mL}$, kemudian ditambahkan 10 $\mathrm{mL} \mathrm{HCl}$ dan dihidrolisis ke dalam autoklaf pada suhu $110^{\circ} \mathrm{C}$ selama 12 jam. Sampel dinetralkan menggunakan $\mathrm{NaOH}$ $6 \mathrm{~N}$ dan ditambahkan sampai dengan $100 \mathrm{~mL}$, setelah itu disaring menggunakan kertas saring ukuran 0,22 $\mu \mathrm{M}$ dan dimasukkan sebanyak $2 \mu \mathrm{L}$ ke dalam alat LC/MS.

\section{Analisis SDS PAGE (Sodium Dodecyl Sulfate-Polyacrylamide Gel Electrophoresis)}

Analisis ini merupakan metode yang digunakan untuk mengetahui berat molekul dari suatu protein. Elektroforesis SDS PAGE diawali dengan mengambil sampel tiap-tiap perlakuan sebanyak $0,2 \mathrm{~g}$, setelah itu sampel dimasukkan ke dalam mikrotub, ditambahkan akuabides $500 \mu \mathrm{L}$ dan divortex hingga larut. Supernatan diambil sebanyak 70 $\mu \mathrm{L}$ dan dimasukkan ke dalam mikrotub baru, kemudian ditambahkan SDS PAGE Protein loading buffer/dye sebanyak $70 \mu \mathrm{L}$ dan direbus dalam air mendidih selama 3 menit. Proses elektroforesis dilakukan dengan mengambil sampel sebanyak $20 \mu \mathrm{L}$ dan dimasukkan ke dalam sumuran (well) elektroforesis dan juga memasukkan marker protein sebanyak $10 \mu \mathrm{L}$ ke dalam sumuran elektroforesis. Alat elektroforesis dinyalakan pada voltase sebesar 110 volt dengan arus litrik sebesar 40 ampere dan di-running sekitar 60 menit. Setelah itu, gel elektroforesis diambil dan direndam ke dalam Commasie Brilliant Blue selama 2 jam atau lebih, kemudian dicuci dengan destaining sambil digoyang selama 30 menit. Gel elektroforesis dicuci menggunakan asam asetat $10 \%$ selama 24 jam, setelah itu hasil elektroforesis dilihat dan diamati serta diukur berat molekul sampelnya.

\section{Analisis data}

Data kepadatan bakteri dianalisis secara deskriptif. Data kandungan nutrien dan zat antinutrien dianalisis menggunakan analisis sidik ragam pada $a=5 \%$. Data dalam bentuk \% (persentase) ditransformasi ke dalam transformasi Arc sin (Steel \& Torrie, 1960). Data yang berbeda nyata selanjutnya dianalisis lanjutan dengan menggunakan Duncan Multiple Range Test (DMRT) untuk menentukan signifikansi di antara perlakuan menggunakan EXCEL macro add-ins DSAASTAT.XLS (Onofri \& Pannacci, 2014) dan IBM SPSS 23 tool.

\section{HASIL DAN PEMBAHASAN}

Hasil

Berdasarkan hasil perhitungan TPC pada media kultur TSB, kepadatan campuran bakteri yaitu sebesar $2,16 \times 10^{9} \mathrm{CFU} /$ $\mathrm{mL}$, sedangkan kepadatan campuran bakteri dalam tepung daun kelor terfermentasi pada media starch agar, skim milk agar dan CMC agar masing-masing sebesar 0,71 $\times 10^{7} \mathrm{CFU} /$

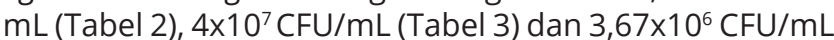
(Tabel 4). Bakteri yang dihitung pada metode TPC adalah bakteri yang hidup.

Perubahan kandungan nutrien dalam tepung daun kelor selama fermentasi terjadi mulai jam ke-24. Kadar air mengalami peningkatan pada jam ke-24 dari 9,04 $\pm 0,00 \%$ menjadi $14,21 \pm 0,08 \%$ dan meningkat kembali pada jam ke-72 sebesar $15,81 \pm 0,58 \%$, dan menurun pada jam ke-96 yaitu sebesar $11,27 \pm 0,55 \%$ kemudian meningkat

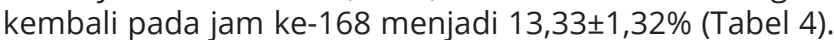
Kadar abu mengalami peningkatan pada jam ke-24 dari $9,70 \pm 0,21 \%$ menjadi $12,87 \pm 0,71 \%$. Setelah mengalami proses fermentasi, kadar abu tepung daun kelor meningkat dengan kisaran 11,92 $\pm 0,03-15,44 \pm 0,26 \%$ (Tabel 4).

Kadar protein juga mengalami peningkatan dari $25,77 \pm 0,08 \%$ (sebelum difermentasi), meningkat pada jam ke-24 dan ke-48 yaitu sebesar $31,05 \pm 0,14 \%$ dan $30,14 \pm 0,15 \%$, kemudian menurun pada jam ke-72 sebesar $28,66 \pm 0,14 \%$ dan mengalami peningkatan kembali sampai

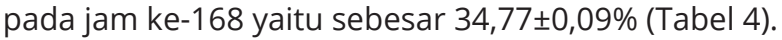

Kadar lemak mengalami peningkatan. Kadar lemak sebelum difermentasi sebesar 4,80 $0,52 \%$ mengalami penurunan menjadi berkisar antara 2,86 $\pm 0,01-4,01 \pm 0,22 \%$ pada jam ke-24 sampai dengan jam ke-96, kemudian mulai jam ke-120 dan ke-144 meningkat menjadi 5,46 $\pm 0,10$ $5,59 \pm 0,15 \%$, dan mengalami peningkatan pada jam ke-168 menjadi 6,25 $\pm 0,13 \%$ (Tabel 4).

Kadar serat kasar mengalami penurunan mulai dari $11,60 \pm 0,13 \%$ (sebelum difermentasi), mengalami penurunan mulai jam ke-24 yaitu sebesar $6,74 \pm 0,05 \%$, meningkat kembali pada jam ke-72 yaitu sebesar $9,65 \pm 0,17 \%$ kemudian menurun hingga jam ke-168. Kenaikan dan penurunan kadar serat dalam tepung daun 
kelor terfermentasi lebih rendah dari kadar serat dalam tepung daun kelor yang tidak difermentasi (Tabel 4).

Kadar bahan ekstrak tanpa nitrogen juga mengalami penurunan setelah difermentasi selama 24 jam, yaitu dari sebesar $39,06 \pm 0,52 \%$ menjadi sebesar 31,84 $\pm 0,76 \%$. Kadar bahan ekstrak tanpa nitrogen mengalami penurunan hingga jam ke-168 (Tabel 4).

Energi mengalami penurunan mulai pada fermentasi jam ke-24 yaitu dari sebesar $351,27 \pm 3,27 \mathrm{kkal} / 100 \mathrm{~g}$ menjadi sebesar 337,04 $\pm 3,47 \mathrm{kkal} / 100 \mathrm{~g}$, kemudian meningkat pada jam ke-120 yaitu sebesar $355,55 \pm 3,42 \mathrm{kkal} / 100 \mathrm{~g}$ dan menurun kembali hingga jam ke-168 menjadi sebesar $351,11 \pm 5,32 \mathrm{kkal} / 100 \mathrm{~g}$ (Tabel 4).
Proses fermentasi menurunkan $(P<0,05)$ kadar hemiselulosa, dari 19,42 $\pm 0,11 \%$ (sebelum difermentasi) menjadi $10,53 \pm 0,64 \%$ pada fermentasi jam ke-24., kemudian mengalami peningkatan pada jam ke-48 dan jam ke-72, serta menurun kembali pada jam ke-96 sebesar 10,03 $\pm 0,66 \%$, kemudian mengalami peningkatan pada jam ke-120 hingga jam ke-168 yaitu berkisar antara 14,42 $\pm 0,07-15,75 \pm 0,73 \%$. Kadar selulosa mengalami penurunan $(P<0,05)$ dari $24,70 \pm 0,22 \%$ (sebelum difermentasi) menjadi berkisar antara $14,49 \pm 0,29-19,14 \pm 0,22 \%$ pada jam ke-168. Kadar lignin mengalami penurunan $(P<0,05)$ yaitu $5,14 \pm 0,31 \%$ (sebelum difermentasi) menjadi 4,92 $0,67 \%$ pada jam ke-24, kemudian mengalami fluktuasi pada setiap jam pengamatan

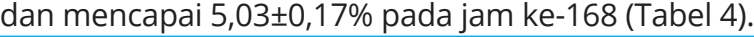

Tabel 4. Kandungan nutrien tepung daun kelor tanpa difermentasi dan tepung daun kelor yang difermentasi dengan campuran bakteri T2A (Bacillus sp.), T3P1 (Bacillus sp.) dan JAL11 (L. raffinolactis) pada setiap waktu pengamatan (dry basis).

\begin{tabular}{|c|c|c|c|c|c|c|c|c|}
\hline \multirow{2}{*}{$\begin{array}{l}\text { Kandungan } \\
\text { Nutrien }\end{array}$} & \multirow{2}{*}{$\begin{array}{l}\text { Tanpa } \\
\text { fermentasi }\end{array}$} & \multicolumn{7}{|c|}{ Waktu fermentasi (jam ke-) } \\
\hline & & 24 & 48 & 72 & 96 & 120 & 144 & 168 \\
\hline Air (\%) & $9,04 \pm 0,00^{a}$ & $14,21 \pm 0,08^{d}$ & $14,21 \pm 0,08^{d}$ & $15,81 \pm 0,58^{e}$ & $11,27 \pm 0,55^{b}$ & $11,66 \pm 0,85^{b}$ & $11,32 \pm 0,62^{b}$ & $13,33 \pm 1,32^{c}$ \\
\hline Abu (\%) & $9,70 \pm 0,21^{\mathrm{a}}$ & $12,87 \pm 0,71^{c}$ & $12,28 \pm 0,25^{b}$ & $11,92 \pm 0,03^{b}$ & $12,29 \pm 0,01^{b}$ & $13,46 \pm 0,07^{d}$ & $15,44 \pm 0,26^{g}$ & $14,05 \pm 0,25^{f}$ \\
\hline Protein (\%) & $25,77 \pm 0,08^{a}$ & $31,05 \pm 0,14^{d}$ & $30,14 \pm 0,15^{c}$ & $28,66 \pm 0,14^{b}$ & $32,20 \pm 0,04^{f}$ & $31,38 \pm 0,04^{e}$ & $33,45 \pm 0,10^{g}$ & $34,77 \pm 0,09^{h}$ \\
\hline Lemak (\%) & $4,80 \pm 0,52^{d}$ & $3,29 \pm 0,12^{b}$ & $2,86 \pm 0,0^{1} a$ & $2,74 \pm 0,21^{a}$ & $4,01 \pm 0,2^{2} \mathrm{c}$ & $5,59 \pm 0,15^{e}$ & $5,46 \pm 0,10^{e}$ & $6,25 \pm 0,13^{f}$ \\
\hline Serat kasar (\%) & $11,60 \pm 0,13^{g}$ & $6,74 \pm 0,05^{a}$ & $6,66 \pm 0,20^{a}$ & $9,65 \pm 0,17^{f}$ & $8,19 \pm 0,37^{d}$ & $7,30 \pm 0,30^{\mathrm{b}}$ & $7,82 \pm 0,12^{c}$ & $8,24 \pm 0,56^{e}$ \\
\hline $\begin{array}{l}\text { Bahan ekstrak } \\
\text { tanpa nitrogen (\%) }\end{array}$ & $39,06 \pm 0,52^{\mathrm{g}}$ & $31,84 \pm 0,76^{e}$ & $33,85 \pm 0,12^{f}$ & $31,22 \pm 0,36^{d}$ & $32,04 \pm 1,18^{e}$ & $30,61 \pm 0,41^{c}$ & 26,51 & $23,36=$ \\
\hline Energi (kkal/100 g) & $351,27 \pm 3,27^{d}$ & $337,04 \pm 3,47^{b}$ & $336,11 \pm 0,46^{b}$ & $315,82 \pm 4,31^{a}$ & $351,14 \pm 2,50^{c}$ & $355,55 \pm 3,42^{d}$ & $349,18 \pm 1,68^{b c}$ & $351,11 \pm 5,32^{c}$ \\
\hline Hemiselulosa (\%) & $19,42 \pm 0,11^{\mathrm{e}}$ & $10,53 \pm 0,64^{b}$ & $12,79 \pm 1,43^{b}$ & $14,87 \pm 0,74^{c}$ & $10,03 \pm 0,6^{6} a$ & $15,75 \pm 0,73^{d}$ & $14,42 \pm 0,07^{c}$ & $14,71 \pm 0,01^{c}$ \\
\hline Selulosa (\%) & $24,70 \pm 0,22^{f}$ & $16,29 \pm 0,43^{b}$ & $17,41 \pm 0,14^{c}$ & $16,98 \pm 0,56^{b}$ & $19,14 \pm 0,22^{\mathrm{e}}$ & $18,97 \pm 0,03^{e}$ & $17,83 \pm 0,48^{d}$ & $14,49 \pm 0,29^{a}$ \\
\hline Lignin (\%) & $5,14 \pm 0,31^{d}$ & $4,92 \pm 0,67^{b}$ & $6,15 \pm 0,04^{d}$ & $4,93 \pm 0,19^{b}$ & $6,24 \pm 0,39$ e & $7,72 \pm 0,30^{f}$ & $4,26 \pm 0,01^{a}$ & $5,03 \pm 0,17$ \\
\hline
\end{tabular}

\section{Keterangan:}

Huruf superskrip yang berbeda pada baris yang sama menunjukkan perbedaan yang signifikan $(P<0,05)$.

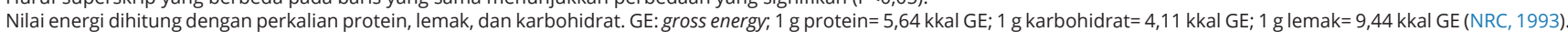

Tabel 5. Kandungan asam amino tepung daun kelor tanpa difermentasi dan tepung daun kelor yang difermentasi dengan campuran bakteri T2A (Bacillus sp.), T3P1 (Bacillus sp.) dan JAL11 (L. raffinolactis) pada setiap waktu pengamatan (dry basis).

\begin{tabular}{|c|c|c|c|c|c|c|c|c|}
\hline \multirow{2}{*}{$\begin{array}{l}\text { Asam amino } \\
\text { (\%) }\end{array}$} & \multirow{2}{*}{$\begin{array}{l}\text { Tidak } \\
\text { difermentasi }\end{array}$} & \multicolumn{7}{|c|}{ Waktu fermentasi (jam ke-) } \\
\hline & & 24 & 48 & 72 & 96 & 120 & 144 & 168 \\
\hline \multicolumn{9}{|l|}{ Esensial } \\
\hline Arginin & $1,10 \pm 0,34^{a}$ & $2,06 \pm 0,03 \mathrm{~g}$ & $1,80 \pm 0,01^{d}$ & $1,92 \pm 0,01^{e}$ & $1,65 \pm 0,04^{\text {bc }}$ & $1,70 \pm 0,04^{c}$ & $2,00 \pm 0,01^{f}$ & $1,54 \pm 0,00^{b}$ \\
\hline Histidin & $0,80 \pm 0,02^{\mathrm{a}}$ & $1,49 \pm 0,06^{f}$ & $1,12 \pm 0,00^{\text {de }}$ & $1,14 \pm 0,02^{\text {de }}$ & $1,08 \pm 0,02^{\mathrm{d}}$ & $0,97 \pm 0,10^{c}$ & $0,90 \pm 0,00^{b}$ & $1,16 \pm 0,00^{e}$ \\
\hline Lisin & $1,27 \pm 0,04^{a}$ & $1,90 \pm 0,04^{d}$ & $1,50 \pm 0,02^{b}$ & $1,59 \pm 0,00^{c}$ & $1,47 \pm 0,04^{b}$ & $1,48 \pm 0,10^{\mathrm{b}}$ & $2,01 \pm 0,00^{e}$ & $1,56 \pm 0,00^{c}$ \\
\hline Fenilalanin & $1,30 \pm 0,01^{c}$ & $1,58 \pm 0,10^{f}$ & $1,29 \pm 0,02^{b}$ & $1,42 \pm 0,18^{e}$ & $1,34 \pm 0,01^{d}$ & $1,81 \pm 0,14^{h}$ & $1,07 \pm 0,23^{a}$ & $1,76 \pm 0,00^{g}$ \\
\hline Isoleusin & $1,21 \pm 0,05^{\mathrm{a}}$ & $1,66 \pm 0,01 \mathrm{e}$ & $1,31 \pm 0,01^{b}$ & $1,43 \pm 0,04^{c}$ & $1,47 \pm 0,00^{c}$ & $1,34 \pm 0,08^{b}$ & $1,62 \pm 0,11^{d}$ & $1,68 \pm 0,00^{f}$ \\
\hline Leusin & $0,23 \pm 0,02^{\mathrm{a}}$ & $1,31 \pm 0,04^{c}$ & $1,88 \pm 0,03^{f}$ & $1,98 \pm 0,048$ & $1,12 \pm 0,02^{d}$ & $1,03 \pm 0,00^{b}$ & $1,80 \pm 0,12^{e}$ & $1,33 \pm 0,00^{d}$ \\
\hline Metionin & $0,04 \pm 0,00^{a}$ & $0,37 \pm 0,02^{b}$ & $0,66 \pm 0,02^{e}$ & $0,43 \pm 0,00^{c}$ & $0,57 \pm 0,02^{d}$ & $0,70 \pm 0,04^{f}$ & $0,81 \pm 0,01^{g}$ & $0,83 \pm 0,00^{h}$ \\
\hline Valin & $0,57 \pm 0,06^{a}$ & $1,27 \pm 0,01^{d}$ & $1,15 \pm 0,12^{b}$ & $1,33 \pm 0,00^{e}$ & $1,36 \pm 0,04^{\text {ef }}$ & $1,36 \pm 0,04^{e f}$ & $1,20 \pm 0,07 c$ & $1,42 \pm 0,00^{g}$ \\
\hline Treonin & $1,36 \pm 0,06^{b}$ & $1,25 \pm 0,22^{\mathrm{a}}$ & $2,22 \pm 0,05^{c}$ & $2,36 \pm 0,11^{\text {de }}$ & $2,61 \pm 0,06^{f}$ & $2,47 \pm 0,08^{e}$ & $2,95 \pm 0,01^{\mathrm{g}}$ & $2,33 \pm 0,00^{\text {cd }}$ \\
\hline \multicolumn{9}{|l|}{ Non esensial } \\
\hline Asam glutamat & $1,77 \pm 0,03^{a}$ & $2,10 \pm 0,39^{b}$ & $2,77 \pm 0,12^{f}$ & $2,79 \pm 0,06^{g}$ & $2,43 \pm 0,03^{e}$ & $2,36 \pm 0,27^{d}$ & $2,31 \pm 0,04^{d}$ & $2,21 \pm 0,00^{c}$ \\
\hline Asam aspartat & $1,30 \pm 0,03^{a}$ & $2,12 \pm 0,03^{b}$ & $2,68 \pm 0,00^{d}$ & $2,76 \pm 0,00^{\text {ef }}$ & $2,78 \pm 0,02^{f}$ & $2,72 \pm 0,04^{\text {de }}$ & $2,40 \pm 0,07^{c}$ & $2,85 \pm 0,0^{\circ} \mathrm{g}$ \\
\hline Serin & $0,36 \pm 0,05^{a}$ & $0,87 \pm 0,05^{b}$ & $2,05 \pm 0,26^{d}$ & $1,84 \pm 0,00^{c}$ & $2,15 \pm 0,03^{d}$ & $2,01 \pm 0,04^{d}$ & $2,01 \pm 0,01^{\mathrm{d}}$ & $1,87 \pm 0,00^{c}$ \\
\hline Alanin & $0,81 \pm 0,03^{a}$ & $1,60 \pm 0,05^{f}$ & $1,32 \pm 0,23^{c}$ & $1,46 \pm 0,07^{e}$ & $1,66 \pm 0,03^{g}$ & $1,79 \pm 0,21^{h}$ & $1,19 \pm 0,04^{b}$ & $1,39 \pm 0,00^{d}$ \\
\hline Tirosin & $0,27 \pm 0,01^{a}$ & $0,38 \pm 0,00^{b}$ & $0,85 \pm 0,06 \mathrm{~g}$ & $0,71 \pm 0,01^{d}$ & $0,79 \pm 0,01^{e}$ & $1,03 \pm 0,00^{h}$ & $0,56 \pm 0,02^{c}$ & $0,87 \pm 0,00^{f}$ \\
\hline Prolin & $0,94 \pm 0,10^{b}$ & $0,47 \pm 0,00^{a}$ & $2,12 \pm 0,14^{d}$ & $2,14 \pm 0,01^{d}$ & $1,94 \pm 0,03^{c}$ & $1,88 \pm 0,00^{c}$ & $2,18 \pm 0,08^{d}$ & $1,88 \pm 0,00^{c}$ \\
\hline Sistein & $0,50 \pm 0,01^{d}$ & $0,51 \pm 0,32^{c}$ & $0,60 \pm 0,19^{f}$ & $0,25 \pm 0,01^{a}$ & $0,41 \pm 0,29 c$ & $0,50 \pm 0,00^{d}$ & $0,30 \pm 0,01^{b}$ & $0,58 \pm 0,00^{e}$ \\
\hline Glisin & $1,30 \pm 0,19^{a}$ & $1,32 \pm 0,16^{b}$ & $2,23 \pm 0,15^{c}$ & $2,41 \pm 0,02^{\text {cd }}$ & $2,55 \pm 0,22^{d}$ & $2,95 \pm 0,00^{f}$ & $2,69 \pm 0,01^{e}$ & $1,49 \pm 0,00^{b}$ \\
\hline Total & $15,13 \pm 0,06$ & $22,26 \pm 0,11$ & $27,55 \pm 0,08$ & $27,96 \pm 0,03$ & $27,38 \pm 0,05$ & $28,10 \pm 0,06$ & $28,00 \pm 0,04$ & $26,75 \pm 0,00$ \\
\hline
\end{tabular}

\section{Keterangan:}

Huruf superskrip yang berbeda pada baris yang sama menunjukkan perbedaan yang signifikan $(P<0,05)$. 
Komposisi asam amino tertinggi dalam tepung daun kelor yang tidak difermentasi yaitu treonin sebesar 1,36+0,06\%, sedangkan terendah adalah metionin sebesar 0,04£0,00\%. Treonin dan metionin termasuk kategori asam amino esensial. Metionin merupakan asam amino esensial pembatas karena mempunyai persentase terendah yang terkandung dalam suatu protein bahan pakan. Komposisi asam amino tertinggi dalam tepung daun kelor terfermentasi yaitu asam aspartat dengan kisaran 2,12+0,03-2,85+0,00\% dan terendah adalah sistein dengan kisaran 0,30+0,01-0,58+0,00\%. Asam aspartat dan sistein termasuk kategori asam amino non esensial (Tabel 5).

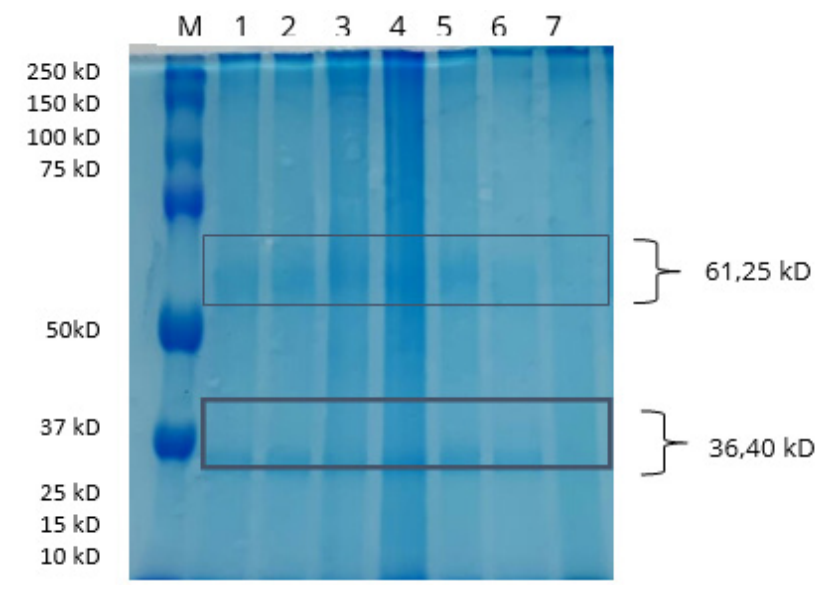

Gambar 1. Pola elektroforesis dalam protein tepung daun kelor terfermentasi.

\section{Keterangan:}

Kolom M: marker; kolom ke-1: fermentasi 24 jam; kolom ke-2: fermentasi 48 jam; kolom ke-3: fermentasi 72 jam; kolom ke-4: fermentasi 96 jam; kolom ke-5: fermentasi 120 jam; kolom ke-6: fermentasi 144 jam; kolom ke-7: fermentasi 168 jam.

Pola elektroforesis dalam protein tepung daun kelor terfermentasi pada kolom ke-1 sampai dengan ke-7 menunjukkan bahwa komponen protein dengan beratmolekul di atas $50 \mathrm{kD}$ dan $25 \mathrm{kD}$ menghilang dari elektroforetogram untuk sampel yang difermentasi selama 168 jam (Gambar 1). Pola elektroforesis menunjukkan bahwa sebagian besar komponen protein tepung daun kelor terfermentasi terdegradasi setelah difermentasi selama 24 jam.

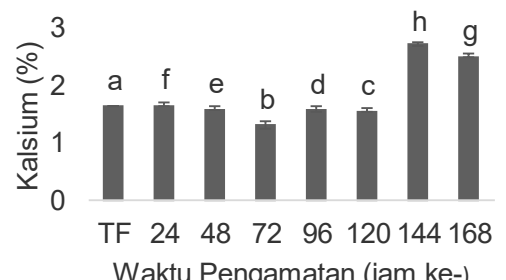

Waktu Pengamatan (jam ke-)

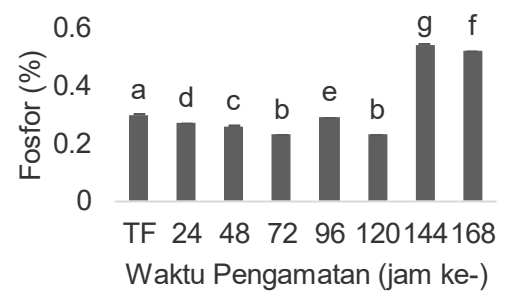

Gambar 2. Kadar kalsium (a) dan fosfor (b) tepung daun kelor yang tidak difermentasi dan tepung daun kelor terfermentasi dengan campuran bakteri T2A (Bacillus sp.), T3P1 (Bacillus sp.) dan JAL11 (L. raffinolactis)

\section{Keterangan:}

$\mathrm{TF}=$ tidak difermentasi

Sampel diuji berdasarkan berat kering (dry basis)

Tepung daun kelor yang tidak difermentasi mengandung kadar kalsium sebesar 1,65 $\pm 0,00 \%$. Selama proses fermentasi, kadar kalsium mengalami fluktuasi. Kadar kalsium mengalami peningkatan $(P<0,05)$ pada jam ke144 dan ke-168 yaitu sebesar $2,72 \pm 0,02 \%$ dan $2,52 \pm 0,03 \%$ (Gambar 2).

Kadar fosfor dalam tepung daun kelor yang tidak difermentasi sebesar 0,30 $\pm 0,00 \%$ dan mengalami fluktuasi nilai selama proses fermentasi. Kadar kalsium mengalami peningkatan $(\mathrm{P}<0,05)$ pada jam ke-144 dan ke-168 yaitu sebesar $0,54 \pm 0,00 \%$ dan $0,52 \pm 0,00 \%$. Rasio kalsium-fosfor tepung daun kelor terfermentasi nilainya berkisar antara 4,84-6,82. Proses fermentasi tersebut meningkatkan kadar kalsium dan fosfor dalam tepung daun kelor (Gambar 2).
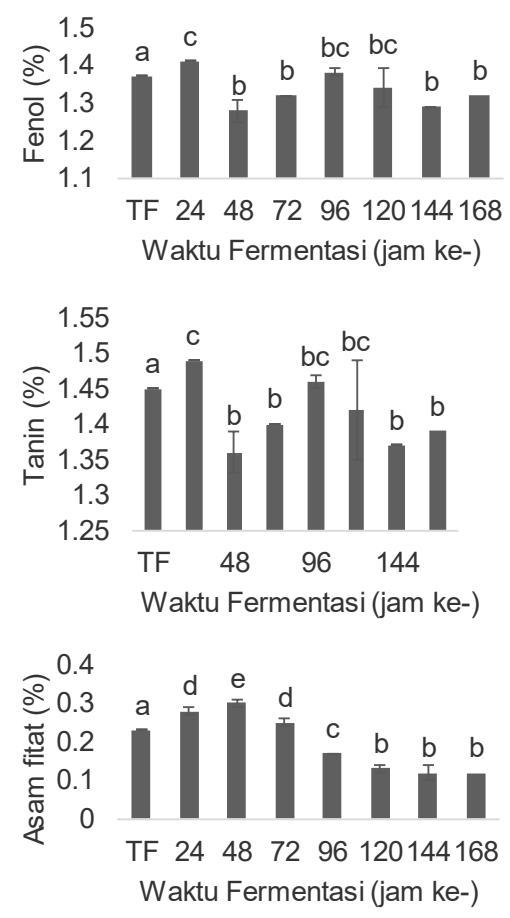

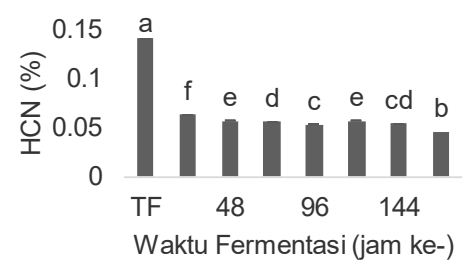

Gambar 4. Kandungan zat antinutrien tepung daun kelor yang tidak difermentasi dan tepung daun kelor terfermentasi dengan campuran bakteri T2A (Bacillus sp.), T3P1 (Bacillus sp.) dan JAL11 (L. raffinolactis)

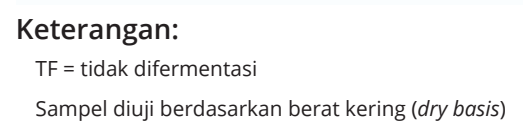

Kandungan fenol, tanin, asam fitat dan HCN dalam tepung daun kelor yang tidak difermentasi lebih tinggi jika dibandingkan dengan tepung daun kelor terfermentasi (Gambar 3). Kadar fenol dalam tepung daun kelor yang tidak difermentasi sebesar 1,37 $\pm 0,00 \%$, sedangkan dalam 
tepung daun kelor terfermentasi berkisar antara 1,28+0,00$1,41 \pm 0,00 \%$. Kadar tanin dalam tepung daun kelor yang tidak difermentasi sebesar 1,45+0,00\%, sedangkan dalam tepung daun kelor terfermentasi berkisar antara 1,36+0,03$1,49 \pm 0,00 \%$. Kadar asam fitat dalam tepung daun kelor yang tidak difermentasi sebesar 0,23 $\pm 0,00 \%$, sedangkan dalam tepung daun kelor terfermentasi berkisar antara $0,12 \pm 0,01-0,28 \pm 0,01 \%$. Kadar HCN dalam tepung daun kelor yang tidak difermentasi sebesar 0,14 $\pm 0,00 \%$, sedangkan dalam tepung daun kelor terfermentasi berkisar antara $0,046 \pm 0,00-0,063 \pm 0,00 \%$. Proses fermentasi tersebut menurunkan kadar fenol, tanin, asam fitat dan HCN dalam tepung daun kelor.

\section{Pembahasan}

Campuran bakteri T2A (Bacillus sp.), T3P1 (Bacillus sp.) dan JAL11 (L. raffinolactis) mempunyai aktivitas proteolitik, amilolitik dan selulolitik, sehingga campuran bakteri tersebut dapat menghasilkan enzim protease, amilase dan selulase. L. raffinolactis merupakan bakteri dari genus Lactococcus yang hidup pada kisaran suhu 10$40^{\circ} \mathrm{C}$. Bakteri tersebut berkembang dengan baik pada $\mathrm{pH}$ 4,5-7,0 dan akan berhenti tumbuh pada $\mathrm{pH}$ di bawah 4,5 (Yu et al., 2017). L. raffinolactis merupakan bakteri asam laktat yang dapat dijadikan agen probiotik karena mampu mengubah karbohidrat (glukosa) menjadi asam laktat serta menurunkan pH (Putri et al., 2014).

Berdasarkan hasil elektroforesis, komponen protein tepung daun kelor terfermentasi mempunyai berat molekul berkisar antara 36,40-61,25 kD. Pola elektroforesis menunjukkan bahwa komponen protein tepung daun kelor tidak tampak setelah fermentasi selama 24 jam. Pola elektroforesis mengalami perubahan dan fermentasi terjadi sampai 168 jam. Berhentinya fermentasi pada jam ke-168 jam terjadi karena kandungan gula telah berkurang akibat reduksi di awal fermentasi yang dapat mempengaruhi produksi alkohol dan asam oleh bakteri. Hal ini menunjukkan bahwa terjadi degradasi yang dapat memperbaiki dan meningkatkan komponen dalam tepung daun kelor terfermentasi. Hal senada disampaikan oleh Weng \& Chen (2010) bahwa mulai terjadi degradasi alergen pada kedelai yang difermentasi selama 24 jam dengan bakteri proteolitik, dan menghasilkan kualitas kedelai yang lebih baik.

Fermentasi tepung daun kelor menggunakan campuran bakteri T2A (Bacillus sp.), T3P1 (Bacillus sp.) dan JAL11 ( $L$. raffinolactis) menghasilkan profil kandungan nutrien yang bervariasi. Fermentasi meningkatkan kadar air dalam tepung daun kelor terfermentasi $(P<0,05)$ yaitu berkisar antara $8,88 \pm 0,58-11,17 \pm 0,08 \%$ atau lebih tinggi daripada tepung daun kelor yang tidak difermentasi yaitu sebesar $9,04 \pm 0,00 \%$. Proses fermentasi dapat meningkatkan kadar air dalam tepung daun kelor yang disebabkan karena kelembaban dalam media selama proses fermentasi tidak lebih tinggi dari laju penguapannya (Moyo et al., 2011; Steven et al., 2015; Nweze et al., 2014).

Fermentasi juga mengubah nilai kadar abu secara signifikan $(P<0,05)$, yaitu berkisar antara 5,81 $\pm 0,03-12,19 \pm 0,26 \%$. Peningkatan kadar abu menunjukkan bahwa daun kelor mengandung bahan-bahan anorganik substansial (Biel et al., 2017). Kadar abu mewakili keberadaan mineral di dalam tanaman (Ihedioha \& Okeye, 2011). Kadar abu yang tinggi di dalam daun menunjukkan bahwa bagian-bagian tersebut merupakan sumber mineral anorganik yang baik (ValdezSolana et al., 2015). Peningkatan kadar abu diduga karena hilangnya bahan kering selama proses fermentasi, sehingga menyebabkan peningkatan relatif dalam komponen yang tidak berubah dari suatu produk fermentasi, terutama serat dan kadar abu (Imelda et al., 2008).

Kadar protein kasar mengalami perubahan dengan durasi fermentasi yang mencapai nilai maksimum pada jam ke168. Fermentasi mengubah kadar protein secara relatif dari $25,77 \pm 0,08 \%$ menjadi berkisar antara 28,66 $\pm 0,14$ $34,77 \pm 0,09 \%(P<0,05)$. Peningkatan yang terjadi secara relatif pada kadar protein tepung daun kelor selama fermentasi disebabkan adanya aktivitas mikroorganisme, biokonversi karbohidrat secara efisien yang terpolimerisasi menjadi protein mikroba dan diproduksinya berbagai jenis enzim yang bersifat proteinase di alam (Vijayakumar, 2003; Bhatnagar, 2004). Kadar protein kasar dalam tepung daun kelor lebih tinggi daripada beberapa jenis tanaman lainnya (Ayssiwede et al., 2010) sehingga daun kelor dapat berfungsi sebagai sumber protein tambahan yang potensial sebagai bahan pakan (Moyo et al., 2011) di samping tepung kedelai.

Proses fermentasi meningkatkan $(P<0,05)$ kadar lemak dalam tepung daun kelor dari 4,80 $\pm 0,52 \%$ menjadi berkisar antara 1,34 $\pm 0,21-3,00 \pm 0,13 \%$. Kadar lemak dari penelitian sebelumnya, sebesar 7,90\% (Richter et al., 2003), 6,50\% (Moyo et al., 2011), 8,50\% (Ganzon-Naret, 2014) dan 0,16\% (Steven et al., 2015). Kadar lemak yang rendah juga dilaporkan oleh Mbailao et al. (2014). Penurunan kadar lemak di awal diduga karena adanya pemanfaatan lemak yang tersedia untuk pertumbuhan campuran bakteri, sedangkan peningkatan kadar lemak yang berangsur-angsur terjadi karena hilangnya bahan kering selama proses fermentasi, sehingga terjadi peningkatan relatif dalam komponen suatu produk fermentasi (Imelda et al., 2008).

Kadar serat kasar mengalami penurunan secara relatif, yaitu berkisar antara 6,66 $\pm 0,20-9,65 \pm 0,17 \%$. Hal ini disebabkan karena adanya kemampuan campuran bakteri dalam mendegradasi serat kasar sebagai komponen dinding sel tanaman, walaupun ada sekresi beberapa enzim (Hassaan et al., 2015). Campuran bakteri dapat menghasilkan enzim selulase yang akan memecah selulosa menjadi selubiosa (Pangestu et al., 2015). Menurunnya kadar serat kasar selama proses fermentasi disebabkan karena adanya enzim yang dapat memecah selulosa menjadi glukosa dari tepung daun kelor. Campuran bakteri dapat memproduksi enzim selulase yang dapat menurunkan kadar serat kasar selama proses fermentasi sehingga lebih mudah untuk dicerna. Enzim selulase merupakan enzim kompleks yang bekerja secara bertahap dalam memecah selulosa menjadi glukosa, kemudian glukosa akan digunakan oleh substrat sebagai sumber karbon dan energi. Menurunnya serat kasar juga berkaitan dengan selulase ekstraseluler dan xilanase yang dihasilkan oleh Bacillus dan Lactococcus.

Proses fermentasi juga menurunkan kadar bahan ekstrak tanpa nitrogen $(P<0,05)$. Penurunan secara relatif ini disebabkan karena karbohidrat memanfaatkan sifat dari bakteri yang tumbuh. Dengan kata lain, massa sel mikroba menerjemahkan kadar bahan ekstrak tanpa nitrogen dalam pakan menjadi protein sebagai kadar protein total tepung 
daun kelor terfermentasi. Mohammed Nour et al. (2013) menyatakan bahwa menurunnya kadar bahan ekstrak tanpa nitrogen selama fermentasi disebabkan karena adanya penggunaan gula sebagai sumber energi oleh mikroorganisme atau dikonversinya menjadi alkohol oleh bakteri asam laktat. Energi yang terkandung dalam tepung daun kelor yang tidak difermentasi sebesar 351,27 $\pm 3,27$ kkal/100 g merupakan nilai tertinggi.

Lignoselulosa tersusun atas tiga fraksi utama, yaitu selulosa, hemiselulosa dan lignin (Kucharska et al., 2018). Proses fermentasi secara relatif menurunkan kadar hemiselulosa, selulosa dan lignin. Penurunan tersebut disebabkan oleh diproduksinya enzim yang relevan oleh mikroorganisme, seperti enzim pendegradasi polisakarida non-pati.

Kualitas protein tergambar dari jumlah asam amino esensial yang terdapat dalam protein kasar. Asam amino adalah konstituen protein organik yang dapat mempengaruhi kuantitas dan kualitas protein. Penelitian ini telah mengidentifikasi sebanyak 17 macam asam amino dalam tepung daun kelor, baik esensial maupun non esensial. Asam amino esensial yang dianalisis, meliputi arginin, histidin, lisin, fenilalanin, isoleusin, leusin, metionin, valin, dan treonin, sedangkan asam amino non esensial yang dianalisis, meliputi asam glutamat, asam aspartat, serin, alanin, tirosin, prolin, sistein, dan glisin.

Proses fermentasi menghasilkan persentase kandungan asam amino dalam tepung daun kelor yang nilainya cukup berfluktuasi. Kualitas protein berbeda-beda tergantung pada jenis dan jumlah asam amino penyusunnya. Imelda et al. (2008) mengemukakan bahwa peningkatan asam amino dalam suatu produk fermentasi, menunjukkan bahwa pemanfaatan karbohidrat sangat sebanding dengan produksi protein selama proses fermentasi. Tabel 5 menunjukkan bahwa nilai komposisi asam amino dalam tepung daun kelor setelah difermentasi mengalami perubahan. Hal ini terjadi karena setelah mengalami pergantian dinding sel polisakarida sebagai akibat dari pengaruh hidrolisis enzimatik pada proses fermentasi, bioavailabilitas dan kecernaan protein akan meningkat sehingga menghasilkan protein yang cukup tersedia (D'Este et al., 2018).

Tepung daun kelor memiliki kandungan mineral yang tinggi, khususnya kalsium, jika dibandingkan dengan jenis tanaman lainnya (Nkafamiya et al., 2010; Moyo et al., 2011). Kalsium dan magnesium sebagai komponen mineral utama dalam tepung daun kelor, sementara fosfor mempunyai porsi lebih kecil, kemudian diikuti oleh kalium dan natrium (Mbailao et al., 2014). Umumnya, kalsium dalam bahan pakan yang berasal dari alam akan memasok jumlah yang cukup untuk memenuhi kebutuhan bagi sebagian besar ikan bersirip. Ketersediaan fosfor pada sebagian besar produk tanaman adalah rendah (NRC, 1993). Rasio kalsium-fosfor pada semua perlakuan dalam penelitian ini nilainya $>1$, yang menunjukkan bahwa tepung daun kelor berpotensi sebagai sumber mineral yang baik dan aman untuk pakan hewan (Ihedioha \& Okoye, 2011; Biel et al., 2017).

Proses fermentasi dapat menurunkan nilai kadar zat antinutrien dalam tepung daun kelor. Proses fermentasi yang dilakukan ini dapat mengurangi zat antinutrien dalam tepung daun kelor. Proses merebus, merendam, memfermentasi dan memanggang mampu mengurangi kandungan zat antinutrien dalam daun kelor (Stevens et al., 2015). Kandungan zat antinutrien dalam tepung daun kelor menunjukkan bahwa campuran bakteri bekerja secara efektif dalam mendegradasi zat antinutrien.

Proses fermentasi menurunkan kadar asam fitat, karena sumber mikroba eksogen dapat memberikan aktivitas fitase tambahan selama proses fermentasi (Kumar et al., 2012). Penurunan disebabkan karena diproduksinya enzim yang relevan oleh mikroorganisme, seperti fitase yang menyebabkan pemecahan substrat antinutrien ini. Akan tetapi, kadar asam fitat dalam tepung daun kelor terfermentasi sebesar 0,12 $\pm 0,01-0,28 \pm 0,01 \%$ ternyata masih lebih rendah jika dibandingkan dengan bahan baku pakan ikan, seperti tepung kedelai sebesar 1,00-1,50\%, tepung rapeseed sebesar 5,00-5,75\% dan tepung wijen sebesar 2,40\% (Francis et al., 2001). Kadar asam fitat dalam pakan dengan konsentrasi di atas 0,5\% dapat merugikan pertumbuhan ikan (Francis et al., 2001).

Kadar fenol, tanin dan HCN dalam tepung daun kelor terfermentasi nilainya masih lebih rendah jika dibandingkan dengan tepung daun Gliricidia sepium yang memiliki kadar total fenol sebesar 7,71\% dan tanin sebesar 7,26\% (Mutayoba et al., 2011). Total fenol yang tinggi perlu dieksplorasi lebih lanjut karena akan berdampak pada kesehatan hewan (Mutayoba et al., 2011). Belum ada batasan pasti terkait toksisitas sianida (HCN) untuk ikan dan masih butuh lebih banyak penelitian untuk menentukan tingkat toleransi sianida bagi ikan (Francis et al., 2001). Tanin merupakan zat antinutrien yang paling tinggi kadarnya dalam tepung daun kelor, diikuti fenol, HCN dan asam fitat (Gambar 4). Tanin dapat mengganggu kecernaan karena memicu aktivitas antitripsin dan antiamilase, membentuk kompleks dengan vitamin B12 dan mengganggu bioavailabilitas protein (Bamidele et al., 2015).

\section{KESIMPULAN}

Proses fermentasi meningkatkan kadar air, abu, protein, lemak, asam amino, kalsium dan fosfor dalam tepung daun kelor. Proses fermentasi juga menurunkan kadar serat kasar, energi, hemiselulosa, selulosa, lignin serta kandungan zat antinutrien (berupa fenol, tanin, asam fitat dan HCN) dalam tepung daun kelor.

\section{DAFTAR PUSTAKA}

AOAC (Association of Analytical Chemist). 2005. Official methods of analysis.W. Horowitz, (eds). Official methods of analysis 18th eds. AOAC. Gaithersburg MD

Ayssiwede S.B., A. Dieng, H. Bello, C.C.A.M. Chrysostome \& M.B. Hane. 2011. Effects of Moringa oleifera (Lam.) leaf meal incorporation in diets on growth performance, carcass and economic characteristics of growing indigenous Senegal chickens. Pakistan Journal Nutrition. 10: 1132-45

Bamidele, N.A., S.O. Obasa, N.B Ikeiwenwe, I. Abdulraheem, A.A. Adeoye \& O.C. Odebiyi. 2015. Effect of dried moringa (Moringa oleifera) seed meal based doets on the growth, hematological, biochemical parameters and histopathology of the African catfish, Clarias gariepinus fingerlings. International Journal of Fisheries and Aquatic Studies. 2 (4): 27-34 
Barrows, F.T., D. Bellis, A. Krogdahl, J.T. Silverstein, E.M. Herman, W.M. Sealey, M.B. Rust \& D.M. Gatlin III. 2008. Report of plant product in aquafeed strategic planning workshop: An integrated, interdisciplinary research roadmap for increasing utilization of plant feedstuffs in diets for carnivorous fish. Reviews in Fisheries Science. 16 (4): 449-455

Bertsch A. \& N. Coello. 2005. A biotechnological process for treatment and recycling poultry feathers as a feed ingredient. Bioresource Technology. 96:1703-1708

Bhatnagar D. 2004. Amylase and protease production by solid state fermentation using Aspergillus niger from mangrove swamp, M. F. Sc. (Mariculture) Dissertation, Central Institute of Fisheries Education, Mumbai, India, 63 pp

Biel W., J. Anna \& L. Ewelina. 2017. Nutritional quality and safety of moringa (Moringa oleifera Lam. 1785) leaves as an alternative source of protein and minerals. Journal of Elementology. 22 (2): 569-579

Chesson, A. 1978. The maceration of linen flax under anaerobic conditions. Journal of Applied Bacteriology. 45 (2): 219-230

D’Este, M., Alvarado-Morales, M., \& Angelidaki, I. 2018. Amino acids production focusing on fermentation technologies - A review. Biotechnology Advances. 36(1): 14-25

Datta, Rathin. 1981. Acidogenic fermentation of lignocellulose-acid yield and conversion of components. Biotechnology and Bioengineering. 23 (9): 2167-2170.

El-Batal A. I. \& H. Abdel Karem. 2001. Phytase production and phytic acid reduction in rapeseed meal by Aspergillus niger during solid state fermentation. Food Research International. 34: 715-720

Francis G., H.P.S. Makkar \& K. Becker. 2001. Antinutritional factors present in plant - derived alternate fish feed ingredient and their effects in fish. Aquaculture. 199 (3-4): 197-227

Ganzon-Naret E.S. 2014. Utilization of Moringa oleifera leaf meals as plant protein sources at different inclusion levels in fish meal based diets fed to Lates calcarifer. ABAH Bioflux. 6 (2): 158-167

Harborne J. B. 1984. Phytochemical methods: a guide to modern technique of plant analysis. 2nd edition, Chapman and Hall, London, 288 pp

Hassaan et al., 2015 Hassaan, M.S., M.A. Soltan \& A.M. Abdel-Moez. 2015. Nutritive value of soybean meal after solid state fermentation with Saccharomyces cerevisiae for Nile tilapia, Oreochromis niloticus. Animal Feed Science and Technology. 201: 89-98

Ihedioha J. N. \& C.O.B Okoye. 2011. Nutritional evaluation of Mucuna flagillipes leaves: an underutilized legume in Eastern Nigeria. American Journal of Plant Nutrition and Fertilization Technology. I (1): 55-63

Imelda J., P. Raj \& D. Bhatnagar. 2008. Effect of solid-state fermentation on nutrient composition of selected feed ingredients. Indian J. Fish. 55 (4):3 27-332
Karina, S., M. Akbar, A. Supriatna \& Z.A. Muchlisin. 2015. Replacement of soybean meal with Moringa oleifera leaf meal in the formulated diets of tilapia (Oreochromis niloticus) fingerlings. AACL Bioflux. 8 (5): 790-795

Kucharska, K., P. Rybarczyk, I. Holowacz, R. Lukajtis, M. Glinka \& M. Kaminski. 2018. Pretreatment of lignocellulosic materials as substrates for fermentation processes. Molecules. 23: 2937

Kumar V., A.K. Sinha \& H.P.S. Makkar, G. De Boeck \& K. Becker. 2012. Phytate and phytase in fish nutrition. Animal Physiology and Animal Nutrition. 96: 335-364

Lovell, T. 1989. Nutrition and Feeding of Fish. An AVI Book. Van Nostrand Reinhold. New York

Lunger A N, E. McLean \& S.R. Craig. 2007. The effects of organic protein supplementation upon growth, feed conversion and texture quality parameters of juvenile cobia (Rachycentron canadum). Aquaculture. 264: 342-352

Mac Faddin, J.F. 1980. Biochemical Tests for Identification of Medical Bacteria. Second Edition. Williams dan Wilkins, Baltimore

Madalla, N., N.W. Agbo \& K. Jauncey. 2013. Evaluation of aqueous extracted moringa leaf meal as a protein source for nile tilapia juveniles. Tanzania Journal of Agricultural Sciences. 12 (1): 53-64

Mbailao M., M. Tarkodjiel \& A. Ngakou. 2014. Proximal and elemental composition of Moringa oleifera (Lam) leaves from three regions in Chad. Journal of Food Resource Science. 3 (1): 12-20

Mohammed Nour, A. A. \& M.A.E.M. Ibrahim. 2013. Effect of supplementation with Moringa leaves powder (MLP) and fermentation on chemical composition, total minerals content and sensory characteristics of sorghum flour. International Journal of Science and Research. 5 (3): 672-677

Moyo B., P.J. Masika, A. Hugo \& V. Muchenje. 2011. Nutritional characterization of moringa (Moringa oleifera Lam.) leaves. African Journal of Biotechnology. 10 (60): 12925-12933

Mutayoba S. K., E. Dierenfeld, V.A. Mercedes, Y. Frances \& C.D. Knight. 2011. Determination of chemical composition and ant-nutritive components for Tanzanian locally available poultry feed ingredients. International Journal of Poultry Science. 10 (5): 350 357

Nkafamiya I. I., S.A. Osemeahon, U.U. Modibbo \& A. Aminu. 2011. Nutritional status of non-conventional leafy vegetables, Ficus asperfolia and Ficus sycomorus. Afr. J. Food Sci. 4 (3): 104-108

National Research Council (NRC). 1993. Nutrient Requirement of Fish. National Academy Press. Washington DC, USA

Nweze, N. Onyekwere \& F.I. Nwafor. 2014. Phytochemical, proximate and mineral composition of leaf extract of Moringa oleifera Lam. From Nsukka, South-Eastern Nigeria. IOSR Journal of Pharmacy and Biological Science. 9 (1): 99-103 
Omnes Marie-Hélène, J. Le Goasduff, H. Le Delliou, N. Le Bayon, P. Quazuguel \& J. H. Robin. 2017. Effects of dietary tannin on growth, feed utilization and digestibility and carcass composition in juvenile European seabass (Dicentrarchus labrax L.). Aquaculture Reports. 6: 21-27

Onofri, A \& E. Pannacci. 2014. Spreadsheet tools for biometry classes in crop science programmes. Commun. Biometry Crop. Sci. 9: 3-13

Pangestu, K.H., W.P. Agustono \& Lokapirnasari. 2015. Kandungan protein kasar dan serat kasar pada daun kacang tanah (Arachis hypogaea) yang difermentasi dengan bakteri Enterobacter cloacae WPL 111 sebagai bahan pakan alternatif ikan. Jurnal IImiah Perikanan dan Kelautan. 7 (2): 165- 68

Putri, F. S, Z. Hasan \& K. Haetami. 2012. Pengaruh pemberian bakteri probiotik pada pelet yang mengandung Kaliandra (Calliandra calothyrsus) terhadap pertumbuhan benih Nila (Oreochromis niloticus). Jurnal Perikanan dan Kelautan. 3 (4): 283291

Qazi J. I., M. Sara \& A.S. Hafiz. 2011. Improving fish feed by yeast solid state fermentation. Punjab Univ. J. Zool. 26 (1): 21-29

Richter N., P. Siddhuraju \& K. Becker. 2003. Evaluation of nutritional quality of moringa (Moringa oleifera Lam.) leaves as an alternative protein source for Nile tilapia (Oreochromis niloticus L.). Aquaculture. 217: 599-611

Seong M., L. Seunghyung, L. Seunghan, S. Yujin, B. Jinho, C. Kyunghoon \& S. C. Bai. 2018. The effects of different levels of dietary fermented plant-based protein concentrate on growth, hematology and nonspecific immune responses in juvenile olive flounder, Paralichthys olivaceus. Aquaculture. 483:196-202

Steven C. G., F.D. Ugese, G.T. Otituju \& K.P. Baiyeri. 2015. Proximate and anti-nutritional composition of leaves and seeds of Moringa oleifera in Nigeria: a comparative study. Agro Science. Journal of Tropical Agriculture Food, Environment and Extension. 14 (2): 9-17
Valdez-Solana M. A., Y.M.G. Veronica, T.V. Alfredo, G.A. Guadalupe, S.P. Jose, J.A.R. Jose \& S.C. Erick. 2015. Nutritional content and elemental and phytochemical analyses of Moringa oleifera grown in Mexico. Journal of Chemistry. Volume 2015, Article ID 860381. Hindawi Publishing Corporation

Vijayakumar M. 2003. Solid state fermentation of oil cakes and wheat flour and evaluation of the products in shrimp feed. M.F.Sc. (Mariculture) Dissertation, Central Institute of Fisheries Education, Mumbai, India, 85pp

Weng T.M. \& M.T. Chen. 2010. Changes of protein in natto (a fermented soybean food) affected by fermenting time. Food. Sci Technol. Res. 16 (6): 537-542

Wheeler E.L. \& R.E. Ferrel, 1971. A method for phytic acid determination in wheat and wheat fractions. Cereal Chemistry 48:312-320

Yamamoto T., Y. Iwashita, H. Matsunari, T. Sugita, H. Furuita, A. Akimoto, K. Okamatsu \& N. Suzuki. 2010. Influence of fermentation conditions for soybean meal in a non-fish meal diet on the growth performance and physiological condition of rainbow trout Oncorhynchus mykiss. Aquaculture. 309: 173180

Yu, J, Y. Song, Y. Ren, Y. Qing, W. Liu \& Z. Sun. 2017. Genome-level comparisons provide insight into the phylogeny and metabolic diversity of species within the genus Lactococcus. BMC Microbiology. 17: 213

Zhang M., Y. Huang, H. Zhao, T. Wang, C. Xie, D. Zhang, X. Wanga \& J. Shenga. 2017. Solid-state fermentation of Moringa oleifera leaf meal using Bacillus pumilus CICC 10440. Journal of Chemical Technology \& Biotechnology. 92: 2083-2089 